\title{
Morphometric study of Rynchotus rufescens testis throughout the year
}

\author{
Baraldi-Artoni, SM. ${ }^{\mathrm{a} *}$, Bottino, $F^{\mathrm{b}}$, Oliveira, $D .^{\mathrm{c}}$, \\ Sobue Franzo, V.', Amoroso, L. ${ }^{\mathrm{c}}$, Orsi, $A M .^{\mathrm{d}}$ and Cruz, ${ }^{\mathrm{e}}{ }^{\mathrm{e}}$ \\ aDepartamento de Morfologia e Fisiologia Animal, Faculdade de Ciências Agrárias e Veterinárias - FCAV, \\ Universidade Estadual Paulista - UNESP, CEP 14884-900, Jaboticabal, SP, Brazil \\ ${ }^{\mathrm{b} C e n t r o}$ Universitário de Araraquara - UNIARA \\ ${ }^{\mathrm{c}}$ Faculdade de Ciências Agrárias e Veterinárias - FCAV, Universidade Estadual de São Paulo - UNESP \\ ${ }^{\mathrm{d}}$ Departamento de Anatomia, Universidade Estadual de São Paulo - UNESP, Campus de Botucatu \\ ${ }^{e}$ Centro de Aqüicultura da UNESP - CAUNESP \\ *e-mail: smbart@fcav.unesp.br
}

Received June 24, 2005 - Accepted October 4, 2005 - Distributed May 31, 2007

(With 2 figures)

\begin{abstract}
The research aimed to study the morphologic variation of the testis, seeking to promote the selection and genetic control of those that present appreciable spermatic production throughout the year. Testis morphology of the Rynchotus rufescens partridge was investigated, analyzing the testis weight, the seminiferous tubules diameter, the thickness of the seminiferous epithelium, the amount of meiotic figures and the thickness of the tunica albuginea. Sixty male partridges were used, divided in 12 groups, and one group per month had the testis collected for the histological routine and the sections were stained using the Hematoxilin-Eosin technique. For the histological sections analysis, morphometric measures were taken, with the aid of an Image Analyzer and the resulting data were submitted to analysis of variance and to Tukey's test. Based on the histological modifications of the seminiferous epithelium and the morphometric analysis, the partridge testis morphology could be divided in four successive phases throughout the year. The reproductive phase occurred in the spring, characterized by the complete spermatogenesis process. The regression phase occurred in the summer, with the involution of the seminiferous epithelium. The rest phase took place in the fall, with spermatogonias presence and some spermatocytes beginning the meiosis. The phase of recrudescence occurred in the winter, with the recovery of the seminiferous epithelium and absence of spermatozoa. In conclusion, the characteristics analyzed revealed a variation over the year, with greater production of spermatozoa in the spring and less in the winter.
\end{abstract}

Keywords: spermatogenesis, partridge, cycle.

\section{Estudo morfométrico do testículo de perdiz Rynchotus rufescens durante o ano}

\begin{abstract}
Resumo
O trabalho teve como objetivo estudar a variação morfológica do testículo, visando promover a seleção e o controle genético de exemplares que apresentem produção espermática apreciável ao longo do ano. A morfologia testicular de perdiz Rynchotus rufescens foi avaliada, analisando o peso do testículo, o diâmetro dos túbulos seminíferos, a espessura do epitélio seminífero, o número de figuras de meiose e a espessura da túnica albugínea. Foram utilizados 60 machos de perdizes, divididos em 12 grupos, sendo que um grupo por mês teve os testículos coletados para a rotina histológica e foram corados pela técnica de Hematoxilina-Eosina. Para a análise dos cortes histológicos, foram realizadas medidas morfométricas, com o auxílio de um Analisador de Imagem e os dados encontrados foram submetidos à análise de variância e teste de Tukey. Baseado nas modificações histológicas do epitélio seminífero e na análise morfométrica, a morfologia testicular da perdiz pôde ser dividida em quatro fases sucessivas ao longo do ano. A fase reprodutiva ocorreu na primavera, caracterizando-se pelo completo processo de espermatogênese. A fase de regressão aconteceu no verão, ocorrendo involução do epitélio seminífero. No outono ocorreu a fase de repouso, com a presença de espermatogônias e alguns espermatócitos em início de meiose, já a fase de recrudescência da perdiz aconteceu no inverno, com a recuperação do epitélio seminífero e ausência de espermatozóides. Em conclusão, as características analisadas revelaram uma variação durante o ano, com maior produção de espermatozóides na primavera e menor produção no inverno.
\end{abstract}

Palavras-chave: espermatogênese, perdiz, ciclo. 


\section{Introduction}

Birds have an intense reproduction rhythm, which is synchronized by seasonal changes of the environment and by external factors, particularly due to the length of days, in the annual cycle, in such a way that the rhythm of the reproduction season is related to the photoperiod (Nicholls et al., 1988). In addition, Cockrem (1995) has reported that the birds' reproduction starts in fall, when they become photosensitive. Owing to economic interest, a lot of investigations have been carried out to study the influence of different photoperiods on the control of the reproductive functions of female fowls (start and maintenance of posture) and of the males (semen production) (Baraldi-Artoni, 1993).

With the modification of the photoperiod according to the seasons of the year, there is generally a great variation in the size and the functional activity of the fowls' gonads. (Lofts and Murton, 1973).

Some testicular histological parameters have been explored in the birds' testis, for the characterization of the annual testicular cycle, such as the seminiferous tubular diameter, the thickness of the seminiferous epithelium, the thickness of the albuginea tunic, the number of interstitial cells, the number of germinative cells and the nuclear diameter of the germinative cells (Fuenzalida et al., 1989, Baraldi-Artoni et al.1997).

Based on these criteria, associated or not with physiological tests of dosages of hypophysial gonadotrophins and testicular hormones, the annual cycles of the testis in some species of birds (Riley, 1936/37; Bailey, 1953) in swans (Breucker, 1982), in antarctic penguins (Pygoscelis papua) (Fuenzalida et al., 1989) and in quail Coturnix coturnix japonica (Baraldi-Artoni et al., 1999) have been described, all of which have presented four different phases: rest, recrudescence, proliferation and regression. These phases took place consecutively in the course of the year, in different months, or in different seasons, and have apparently presented, as the main exogenous influence on their occurrence and duration, the length of the photoperiod.

In analysing the testicular cycle of some fowls, one can observe that the increase of the testicular weight in winter is independent of the increase of length of light similarly to that which has been observed in the partridge Perdix perdix (Sharp et al., 1986).

Considering that gonadal maturity is in accordance with phonological conditions, any of the four seasons may vary from year to year and according to nourishment, water, environmental temperature, etc. (Wingfield et al., 1992).

A study of the reproductive cycle of males of Nothura maculosa has been conducted monthly in Butiá, Rio Grande do Sul, Brazil, from September 1980 to January 1982. Seasonal changes in the testis were histologically described. The growth of the testis started with a small increase of the photoperiod, whereas their regression occurred when the duration of the days was already decreasing. In this population the males became sexually active for six months, i.e, from September to February (Burger, 1992).

Therefore, considering the lack of knowledge of the reproductive biology about the Brazilian birds, and having the public agencies use methods and techniques poorly suitable to the populational control of some species of birds which make up our fauna, the purpose of this paper consists of reporting a study on the testicular cycle of the partridge Rynchotus rufenscens. The objective of this work seeks to analyze some peculiarities of the partridge Rhynchotus rufescens, such as testicular development, in order to promote the selection and genetic control of those that present considerable spermatic production, through spermatic behavior during the year.

\section{Material and Methods}

Sixty males of the Rynchotus rufenscens partridge were euthanased in the period of March to January (five per month) with ethyl ether. After the laparotomy, and the uncovering of the sternal breastplate and evisceration of the alimentary tract, the testis were removed. Sections were made, immersed in Bouin and later dehydrated in $70 \%$ alcohol, according to techniques of histological routine. The testis were embedded in Paraplast (Sigma ${ }^{\circledR}$ ) and histological sections were obtained from each animal to be later stained using the hematoxylin-eosin technique.

For each animal two histological glasses were filled with five histological sections, chosen at random 20 cross sections to obtain the morphometric measures of the diameter of the seminiferous tubules, thickness of the germinative epithelium, number of figures of meiosis and thickness of the albuginea tunic of the seminiferous tubules per histological glass. All the morphometric measures were obtained with the aid of a Pro-Plus Image Analyser of Olympus, Media Cybernetics, and later the data were analyzed through variance analysis.

\section{Results}

By analyzing the results of the diameter of the seminiferous tubules and of the thickness of the germinative epithelium of the partridge's testis (Rynchotus rufescens) during the year, it was observed that the values in spring were higher $(p<0.05)$ in relation to the ones in fall, winter and summer (Table 1 and Figure 1).

Concerning the number of figures of meiosis, the values from spring were also higher $(p<0.05)$ than those from other seasons, while data from fall and winter were similar (Table 1 and Figure 1).

Values of the thickness of the albuginea tunic were different ( $p>0.05)$, so that the highest and the smallest values occurred in winter and summer, respectively (Table 1 and Figure 1).

Fall, winter and summer were similar for the following parameters: diameter of the seminiferous tubules and thickness of the germinative epithelium, but the number of figures of meiosis became much bigger in spring. 
Table 1. Average values \pm standard deviation and analysis of variance of the seminiferous tubules diameter $(\mu \mathrm{m})$, thickness of the germinative epithelium $(\mu \mathrm{m})$, number of meiosis figures and albuginea tunic thickness $(\mu \mathrm{m})$ of the partridge Rynchotus rufescens testis collected in the period of March, 2002 to January, 2003 (number of animals =60).

\begin{tabular}{lcccc}
\hline Season & $\begin{array}{c}\text { Seminiferous tubules } \\
\text { diameter }\end{array}$ & $\begin{array}{c}\text { Thickness of the } \\
\text { germinative epithelium }\end{array}$ & $\begin{array}{c}\text { Number of meiosis } \\
\text { figures }\end{array}$ & $\begin{array}{c}\text { Albuginea tunic } \\
\text { thickness }\end{array}$ \\
\hline Fall & $183.40 \pm 69.49^{\mathrm{B}}$ & $61.78 \pm 4.16^{\mathrm{B}}$ & $118.95 \pm 22.67^{\mathrm{C}}$ & $106.03 \pm 23.34^{\mathrm{B}}$ \\
Winter & $182.75 \pm 54.98^{\mathrm{B}}$ & $49.67 \pm 24.90^{\mathrm{B}}$ & $114.21 \pm 40.10^{\mathrm{C}}$ & $125.75 \pm 19.15^{\mathrm{A}}$ \\
Spring & $315.91 \pm 57.72^{\mathrm{A}}$ & $79.52 \pm 22.39^{\mathrm{A}}$ & $228.22 \pm 25.59^{\mathrm{A}}$ & $83.25 \pm 5.22^{\mathrm{C}}$ \\
Summer & $190.52 \pm 43.23^{\mathrm{B}}$ & $61.18 \pm 15.19^{\mathrm{B}}$ & $141.52 \pm 22.50^{\mathrm{B}}$ & $24.99 \pm 14.54^{\mathrm{D}}$ \\
\hline
\end{tabular}

*Differents letters in same column have statistic significance $(\mathrm{P}<0,05)$

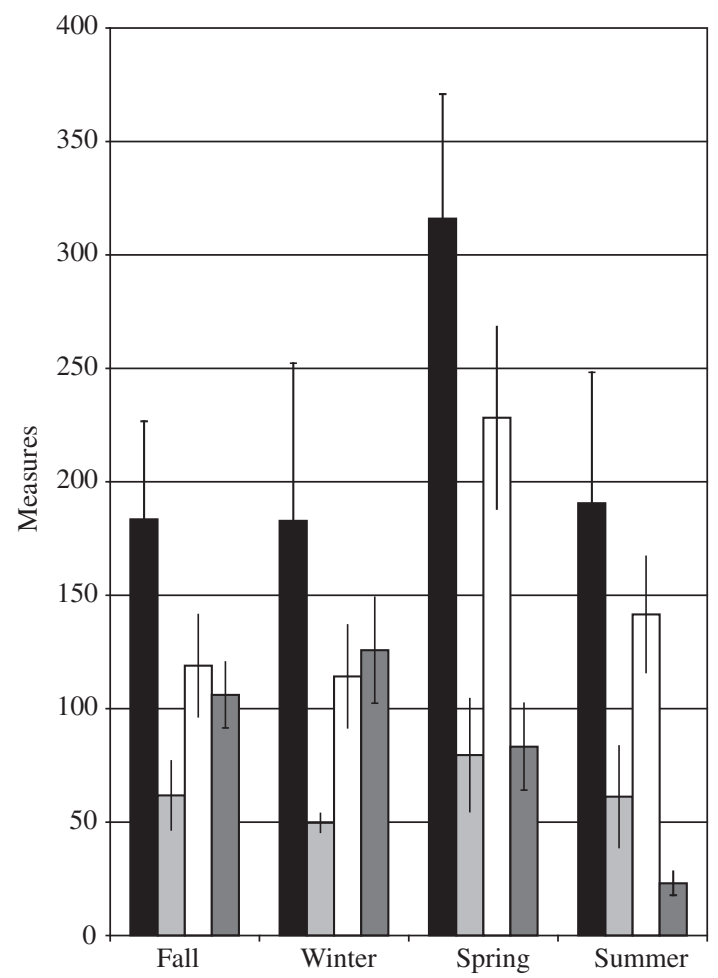

$\square$ Diameter
$\square$ Germinative epithelium thickness
$\square$ Number of meiosis figures
$\square$ Albuginea tunic thickness

Figure 1. Averages of the diameter values of the seminiferous tubules $(\mu \mathrm{m}) \pm$ standard deviation of the thickness average of the germinative epithelium $(\mu \mathrm{m})$, number of meiosis figures and albuginea tunic thickness $(\mu \mathrm{m})$ of the partridge Rynchotus rufescens testis collected in the period of March, 2002 to January, 2003 (number of animals $=60$ ).

Partridges collected in winter presented a relatively thick albuginea, with an average of $125.75 \pm 23.34 \mu \mathrm{m}$ as compared to the albuginic thickness of spring, being on average $83.25 \pm 5.22 \mu \mathrm{m}$ of thickness. Concerning fall and winter, one can also observe that the albuginea tunic in winter were thicker $(\mathrm{p}<0.05)$ in relation to fall and summer, revealing the decline of reproductive activity in winter, as can be noted in Figure 1. The analyzed parameters presented a significant difference between spring and the other seasons, characterizing the reproductive phase of the partridge (Table 1 and Figure 1).

Based on the histological modifications of the seminiferous epithelium and in the morphometric analysis, the testicular cycle of the partridge may be divided into four consecutive phases in the course of the year (Figure 2). The reproductive phase (activity phase) occurs in spring, being characterized by the complete process of the spermatogenesis, with primary spermatogonia, spermatocites in different stages of meiotic division, rounded and elongated spermatides, and a lot of spermatozoa in the tubular lumen being observed (Figure 2a).

The regression phase occurred in summer, with the involution of the Seminiferous epithelium of the partridge. The tubular lumen appears full of germinative cells and spermatozoa (Figure $2 b$ ).

The rest phase occurs in fall, presenting seminiferous tubules with presence of spermatogonia disposed in layers and some spermatocites at the beginning of the meiotic division (Figure 2c). The recrudescence phase takes place in winter, being characterized by the recovery of the Seminiferous epithelium, with incomplete process of the spermatogenesis and absence of spermatozoa (Figure 2d).

\section{Discussion}

Breucker (1982) has worked with testis of sexually mature swans Cygnus olor and considered that an adequate parameter to evaluate the variation of spermatogenic activity is the variation of the seminiferous tubular diameter. The seminiferous tubular diameter of the swan shows a progressive increase in winter and maximum values in spring (proliferation period) with a decrease in summer and fall (periods of sexual regression and rest).

In Coturnix coturnix japonica, Baraldi-Artoni et al. (1999) have observed that tubular diameters, thickness of the germinative epithelium and number of testicular figures of meiosis present maximum and minimum values in the months of September (spring) and May (fall), respectively. In the partridge testis collected in winter, one has found smaller relative values as to the diameter of the seminiferous tubules and thickness of the germinative epithelium and approximately similar values as to the number of germinative cells of quail collected in the month of July (Baraldi-Artoni, 1993). 


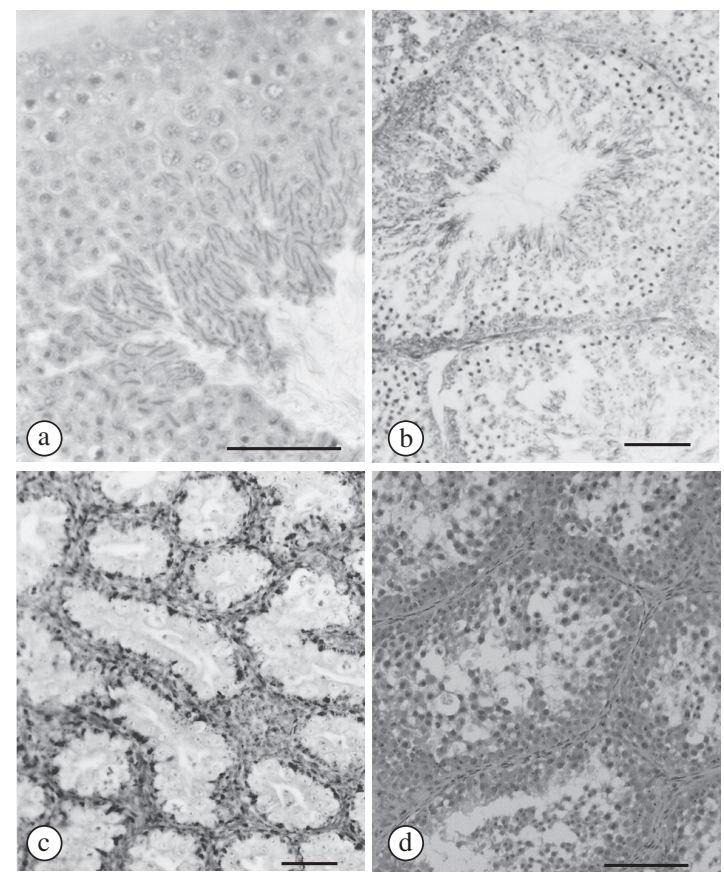

Figure 2. Seminiferous tubules of the adult partridge in: a) spring; b) summer; c) fall; and d) winter. Observe the diameter of the seminiferous tubules $(\mathrm{H} \& \mathrm{E})$. Bar $=50 \mu \mathrm{m}$.

In spring, a period of spermatogenic proliferation, the partridge testis presents seminiferous tubules with very developed tubular diameters, a maximum thickness of germinative epithelium, an elevated number of germinative cells and a very lean albuginea tunic in relation to the values observed in winter, values also observed by Baraldi-Artoni (2002).

In relation to the average thickness of the penguin's albuginea tunic (Pygocelis papua), Fuenzalida et al. (1989) have observed that it is lean or thick in the periods of activity or spermatogenic regression, respectively. Thus, similar data have been found in partridges.

In the domestic duck, Simões et al. (2003) have identified four phases: reproduction (October), regression (November and December), rest (January and February) and recrudescence (March to June). Thus, we can observe that certain phases of the testicular phase of the rooster (De Reviers, 1971), the swan (Breucker, 1982) and the quail (Baraldi-Artoni et al., 1997) are similar to the testicular cycle of the partridge Rynchotus rufescens.

The morphometric analysis of the testicular parameters of the dove Zenaida auriculata shows the existence of a concise testicular cycle, characterized by the reproductive phase with maximum values in fall, a regression phase with minimum values in winter and a recrudescence phase in summer, but the rest phase has not been made clear in this species (Santos et al., 2002). The grey partridge (Perdix perdix) did not present an increase in testis weight during the year as observed by Sharp et al. (1986).

\section{Conclusions}

The present data concerning seminiferous tubules diameter, thickness of the germinative epithelium, number of meiosis figures and albuginea tunic thickness revealed a variation over the year. The highest seminiferous tubules diameter, thickness of the germinative epithelium, and number of meiosis figures were detected during the spring and the albuginea tunic thickness was thicker in the winter, demonstrating that the greater spermatozoa production occurs in the spring and the least occurs in the winter.

Acknowledgments - We acknowledge the financial support of Fundação de Apoio à Pesquisa do Estado de São Paulo (FAPESP) and Fundunesp.

\section{References}

BAILEY, RE., 1953. Accessory reproductive organs of male fringillid birds: seasonal variations and response to various sex hormones. Anat. Rec., vol. 115, no. 1, p. 1-19.

BARALDI-ARTONI, SM., 2002. Características morfológicas do sistema genital masculino de perdiz (Rhynchotus rufescens), Jaboticabal, 2002. Tese (livre-docência) - Depto. de Morfologia e Fisiologia Animal, Universidade Estadual Paulista, 100 p.

-, 1993. Considerações sobre a morfologia e a histofisiologia do testículo da codorna Coturnix coturnix japonica, Botucatu, 1993. Tese (doutorado em Ciências Biológicas) - Instituto de Biociências, Universidade Estadual Paulista, 77 p.

BARALDI-ARTONI, SM., ORSI, AM., LAMANOCARVALHO, TL. and LOPES, RA., 1997. The annual testicular cycle of the domestic quail (Coturnix coturnix japonica). Anat. Histol. Embryol., vol. 26, p. 337-339.

BARALDI-ARTONI, SM., ORSI, AM., LAMANOCARVALHO, TL., VICENTINI, CA. and STEFANINI, MA., 1999. Seasonal Morphology of the Domestic Quail (Coturnix coturnix japonica) Testis. Anat. Histol. Embryol., vol. 28, p. $217-20$.

BREUCKER, H., 1982. Seasonal spermatogenesis in the mute swan (Cygnus olor). Anat. Embryol. Cell Biol., vol. 72, p. 1-91.

BURGER, M., 1992. Ciclo reprodutivo de machos de uma população de Nothura maculosa temminck, 1815 (Aves; Tinamidae) no Rio Grande do Sul, Brasil. Iheringia, no. 73, p. 77-90.

COCKREM, JF., 1995. Timing of seasonal breeding in birds, with particular reference to New Zealand birds. Reprod. Fertil. Dev., vol. 7, p. 1-19.

DE REVIERS, M., 1971. Le développment testiculaire chez le coq. II Morphologie de l'épithelium séminifere et établissement de la spermatogenese. Ann. Biol. Anim. Biochem. Biophys., vol. 11 , p. 531-46.

FUENZALIDA, H., LEYTON, V., VALENCIA, J., BLANQUEZ, MJ. and GONZALEZ, ME., 1989. Morfologia del testiculo de Pygoscelis papua (FOSTER) durante el periodo de actividade sexual. Arch. Anat. Embryol., vol. 20, p. 79-81.

LOFTS, B. and MURTON, RK., 1973. Reproduction in birds. Avian Biol., vol. 3, p. 1-107. 
NICHOLLS, TJ., GOLDSMITH, AR. and DAWSON, A., 1988. Photofractoriness in birds and comparison with mammals. Physiol. Rev., vol. 68, p. 133-76.

RILEY, GM., 1936/37. Experimental studies on spermatogenesis in the house sparrow, Passer domesticus (Linnaeus). Anat. Rec., vol. 67, p. 327-351.

SANTOS, VC., BARALDI-ARTONI, SM., WHERTER, K., 2002. Ciclo testicular da pomba Zenaida auriculata. Investigação, vol. 6, p. 12-15.
SHARP, PJ., MASSA, R., BOTTONI, L., LUCINI, V., LEA RW., DUNN, IC. and TROCCHI, V., 1986. Photoperiodic and endocrine control of seasonal breeding in Grey partridge (Perdix perdix). J. Zool., vol. 209, p. 187-200.

SIMÕES, K., ORSI, A. and CRUZ, C., 2003. Ciclo espermatogenético do pato doméstico (Anas platyhrynchos). Congresso de integração em Biologia da Reprodução. Anais... Ribeirão Preto.

WINGFIELD, JC., HAHN, TP., LEVIN, R. and HONEY, P., 1992. Environmental Predictability and control of gonadal cycles and birds. J. Exp. Zool., vol. 261, p. 214-231. 
